\title{
Mapping the Dyke Swarms of the Neoproterozoic Basement in Southwestern Jordan Using Remote Sensing and GIS Techniques
}

\author{
Usama F. Zaineldeen ${ }^{1}$ \\ ${ }^{1}$ Department of Geology, Al Azhar University - Gaza, Gaza, Palestine \\ Correspondence: Usama F. Zaineldeen, Department of Geology, Al Azhar University - Gaza, P.O. Box 1277, \\ Gaza, Palestine. E-mail: u.zain@alazhar-gaza.edu
}

Received: September 1, 2012

Accepted: October 25, 2012 Online Published: November 28, 2012

doi:10.5539/esr.v2n1p156

URL: http://dx.doi.org/10.5539/esr.v2n1p156

\begin{abstract}
The current study documents for the first time the existence of four suites of dykes intruded the Neoproterozoic crustal rocks in southwestern Jordan. The oldest suite strike E-W followed by suites strike NE-SW, N-S and NW-SE which is the youngest one. Remote sensing and GIS techniques were used for mapping the dykes observed at the satellite image of the study area. Landsat Thematic Mapper color composite scenes allowed mapping of most the dyke swarms in the study area. Digital image processing technique was performed to map the dyke swarms in the study area. The emplacement of the dykes is consistent with extensional continental tectonic setting during the Precambrian time and before the deposition of the Cambrian sediments. The study gives an evidence for an anticlockwise rotation of the extensional stress regimes that caused these suites of dykes. Remote sensing and GIS technique used here could thus guide the interpretation and provide exact and accurate dyke mapping tools.
\end{abstract}

Keywords: Jordan, Dykes, Arabian - Nubian Shield, Araba complex

\section{Introduction}

The Neoproterozoic of the basement of southwestern Jordan is the northernmost part of the Arabian-Nubian Shield. The basements are exposed along the eastern margin of Wadi Araba (Figure 1). Dyke swarms are the most obvious features of the basement with different direction. The Arabian-Nubian Shield formed during Neoproterozoic time (1000-540 Ma) along both sides of the Red Sea (Bentor, 1985; Stern, 1994). The shield formed in two major events. The first one took place between 900 and $600 \mathrm{Ma}$ (Bentor, 1985; Jarrar, 1985; Stoeser \& Camp, 1985; Stern, 1994). The second stage (600-540 Ma) was dominated by NW-trending strike-slip faults, strong extension which was accompanied by bimodal magmatic activity and the deposition of molasse type sediments (e.g. Stern, 1985; Jarrar et al., 1991; Jarrar et al., 1992). The dyke intrusion was occurred during the second stage of the shield formation.

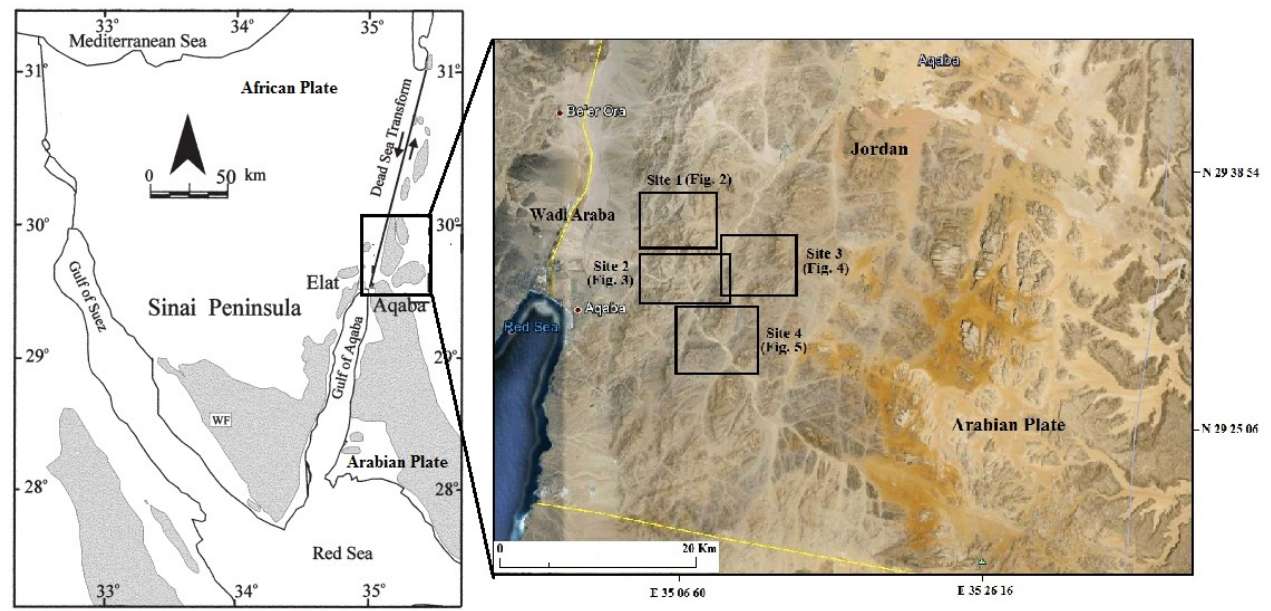

Figure 1. Location map of the study area showing the location of the four sites 
The dykes swarms have been investigated in Jordan by Jarrar et al. (1992) and Zaineldeen et al. (2002), in Saudi Arabia by Jackson et al. (1984), in southern Israel by Beyth et al. $(1994,1995)$ and Kessel et al. (1998), in Sinai by Friz-Töpfer (1991), Stern and Manton (1987) and in Eastern and Western deserts of Egypt by Stern and Gottfried (1986), Stern and Voegeli (1987), Stern et al. (1988), Pudlo and Franz (1994).

The integrated use of remote sensing data and GIS technique, with field ground surveys, are well known as powerful techniques for such mapping of the dyke swarms. Remote sensing data is used for extracting and analyzing geological structures and surface morphology. Moreover, it provides a better observation and more systematic analysis of various geomorphic units, landforms and lineament features. Remote sensing data and GIS techniques can be used to prepare and to analyze different maps. Remote sensing and GIS techniques have been used in this study to process and analyze the Landsat imagery for the study area in order to locate the zones for dykes since its difficult to do so in the field ground survey.

The main objective of the present study is to apply remote sensing and GIS techniques approach to process and analyze the digital image for identification and delineation prospective dyke zones and finally build up a map for these dykes for the investigated area. The advantage of such methods is to conduct regional and cost-effective investigations over large areas as is the case with the study area.

\section{Study Area}

The study area is located in southwestern part of Jordan to the east of the southern Wadi Araba Fault, the southern segment of the Dead Sea Rift (Figure 1). It is bounded by latitudes $29^{\circ} 20^{\prime}$ and $30^{\circ} 16^{\prime}$ North and longitudes $35^{\circ} 00^{\prime}$ and $36^{\circ} 00^{\prime}$ East. It is located in the northwestern part of the Arabian plate separated from the African Plate along the most profound tectonic event on the earth crust (Dead Sea Rift / Transform).

The investigated area includes many important geomorphological features such as mountainous desert, mountain ridges, highlands, plateau and wadis.

The methodology of the study depended mainly on satellite images as well as An ArcGIS program. Field observations have been used. Landsat images were used to interpret the occurrence of the dyke swarms. While the ENVI 4.7 software was used for processing and the ArcGIS version 9.3.1 software packages were applied to digitize of the dyke swarms maps.

The study area was divided into four sites where the dykes swarm concentrated (Figure 1) to be easy to extract the delineated dykes as much as it can be. These sites are shown on Figures 2, 3, 4 and 5. Three-dimensional view was constructed for the study area (Figures 6 and 7).

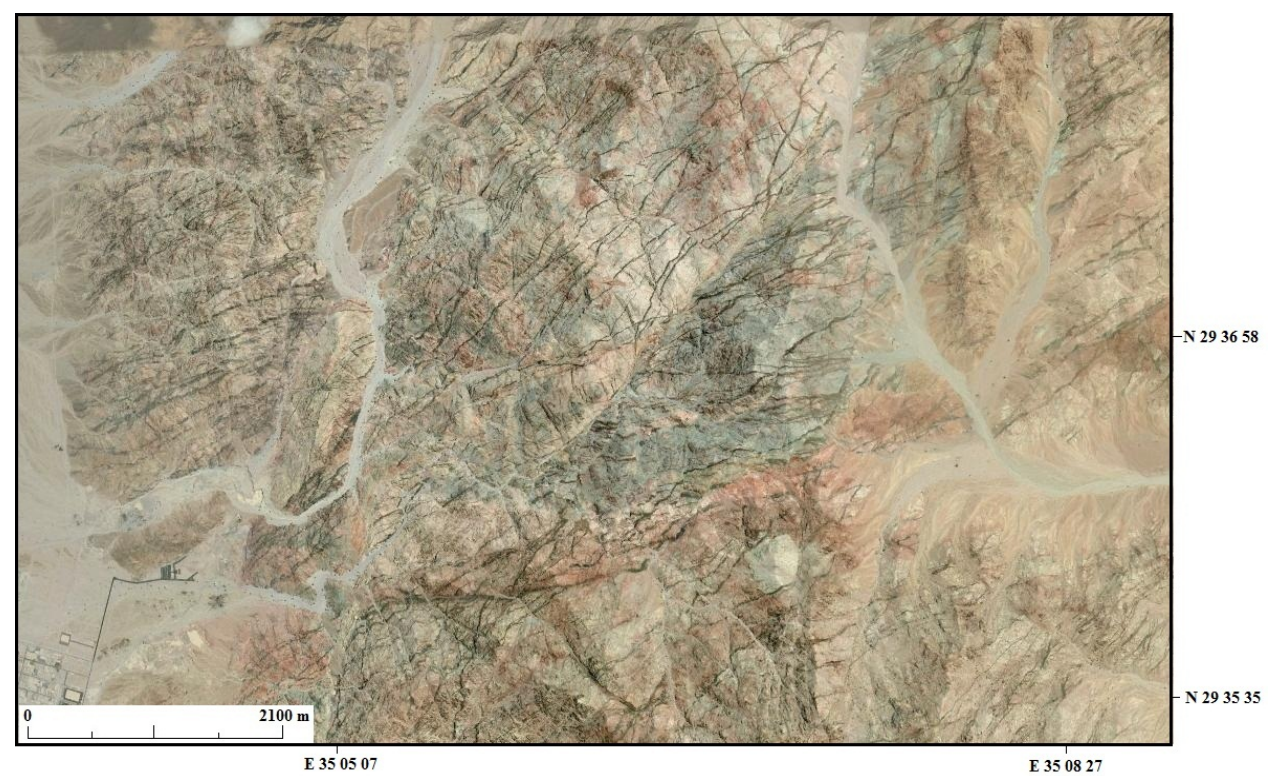

Figure 2. Displaying dykes with bands 7, 3 and 2 at site 1 of the study area (see Figure 1 for location)

Most of the study area is covered by Neoproterozoic crystalline basement. The basement of southwest Jordan constitutes the northernmost exposed portion of the Arabian-Nubian Shield. It is comprised principally of felsic 
igneous rocks with subordinated felsic and basic volcanics. The shield in southern Jordan has been subdivided into the lower Aqaba Complex, comprised of a sequence of schistose and gneissic metamorphic remnants and plutonic igneous rocks, and the overlying Araba Complex, made up principally of alkaline, rhyolitic lavas and subvolcanic intrusions. The two complexes are separated by an unconformity marked by the Saramuj Conglomerate Formation (Jarrar, 1985). The Aqaba plutonic rocks are calc-alkaline in character ranging in age from 620 to $570 \mathrm{Ma}$ (Ibrahim \& McCourt, 1995). Most of the study area is covered by these rocks where the studied dykes are intruded.

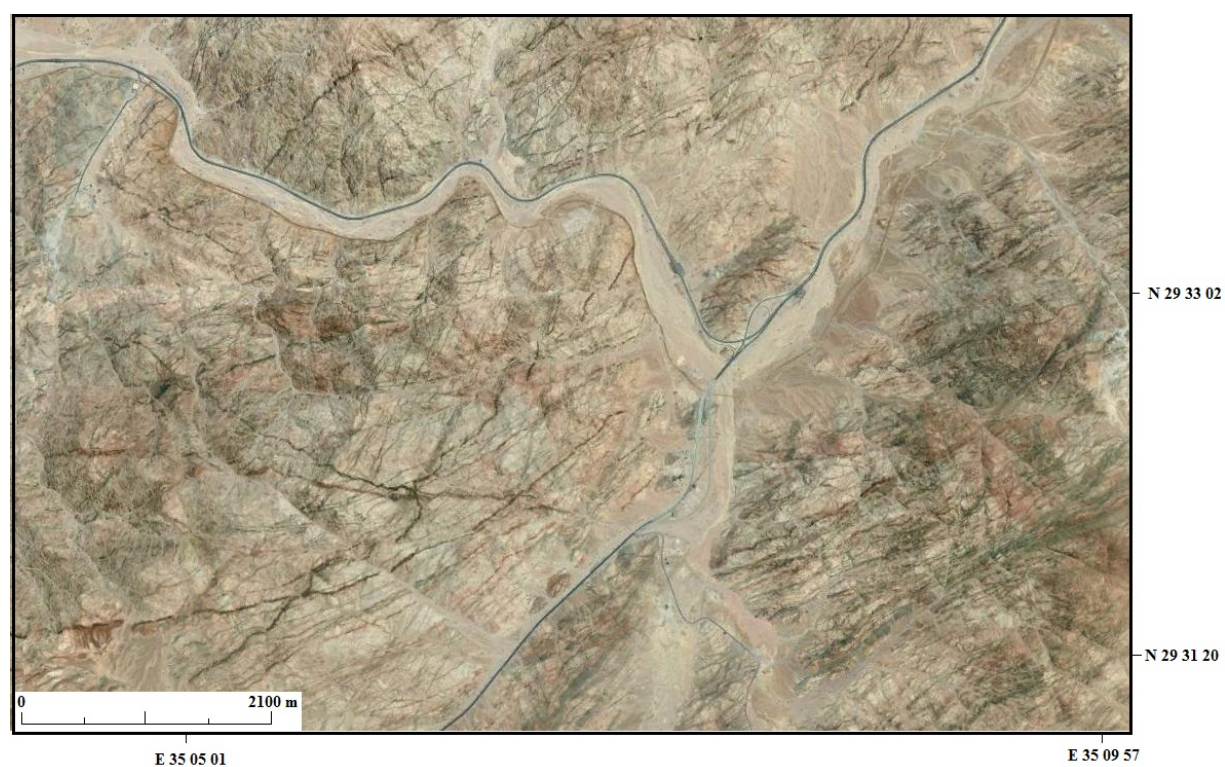

Figure 3. Displaying dykes with bands 7, 3 and 2 at site 2 of the study area (see Figure 1 for location)

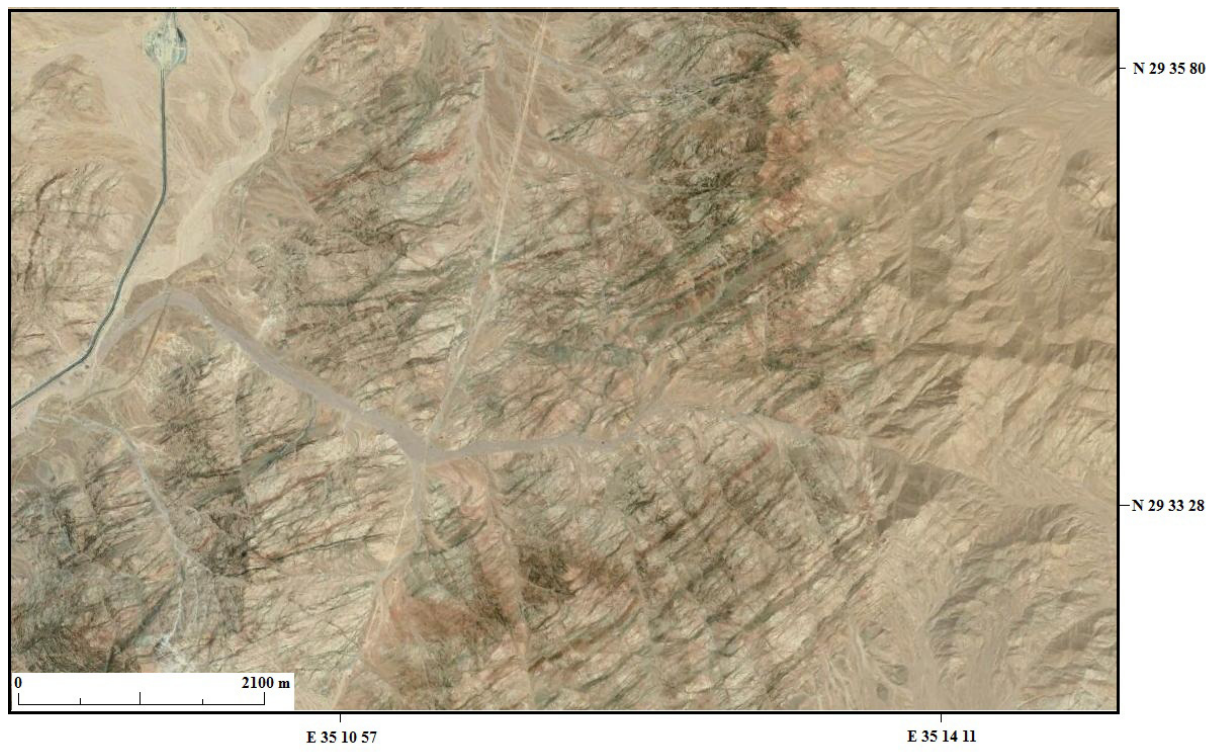

Figure 4. Displaying dykes with bands 7, 3 and 2 at site 3 of the study area (see Figure 1 for location)

The Arabian-Nubian Shield is generally regarded as a series of Neoproterozoic intra-oceanic island arcs and sialic microcontinents in which are incorporated a few slivers of oceanic lithosphere (ophiolites). Arc magmatism and terrane accretion commenced around $950 \mathrm{Ma}$ with the new continental crust being attached to the African craton during the Panafrican orogeny. Extensional tectonism and granitic plutonism, followed by anorogenic magmatism, uplift and erosion between 620 to 540 Ma marked the final stages of cratonistion. 


\section{Methodology}

In order to delineate and digitize the dykes of the basement of the study area, the remote sensing data of Landsat imagery and ArcGIS software were used. The satellite image of the study area was acquired by Landsat TM5 on August 08, 1985. The ENVI 4.7 (Environment for Visualizing Images) software was used for image processing with bands 7,3 and 2. Linear stretching procedure was used for image enhancement. The ArcGIS 9.3.1 software packages were applied to extract dykes, topography and digitize of the geological maps. The visual interpretation of satellite image allowed the mapping of most dykes in the study area. The method gives an excellent maps for these dykes. Maps for these suites of dykes have been created using remote sensing and GIS techniques (Figure $8,9,10$ and 11). The methodology is based on digitizing the dykes zones that observed at the satellite image. Dyke emplacement constitutes one of the conspicuous features at the satellite image of the study area.

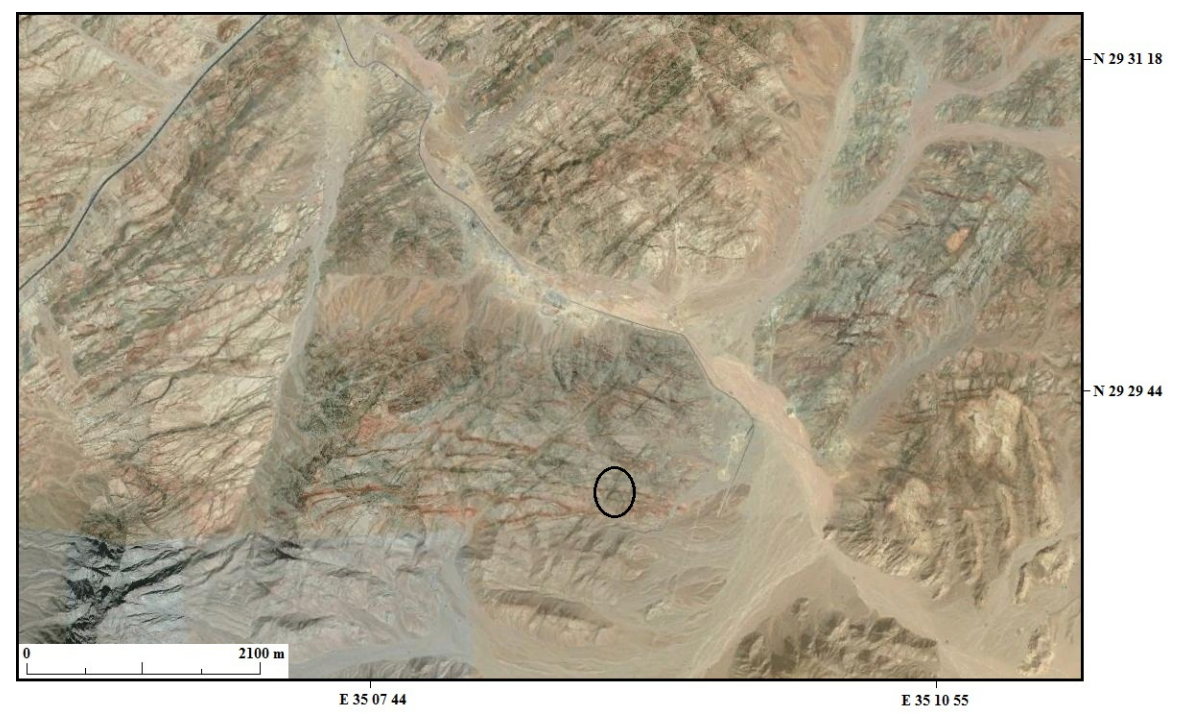

Figure 5. Displaying dykes with bands 7, 3 and 2 at site 3 of the study area (see Figure 1 for location). Marked circle is the place where the NE-SW striking dykes cut the E-W striking ones

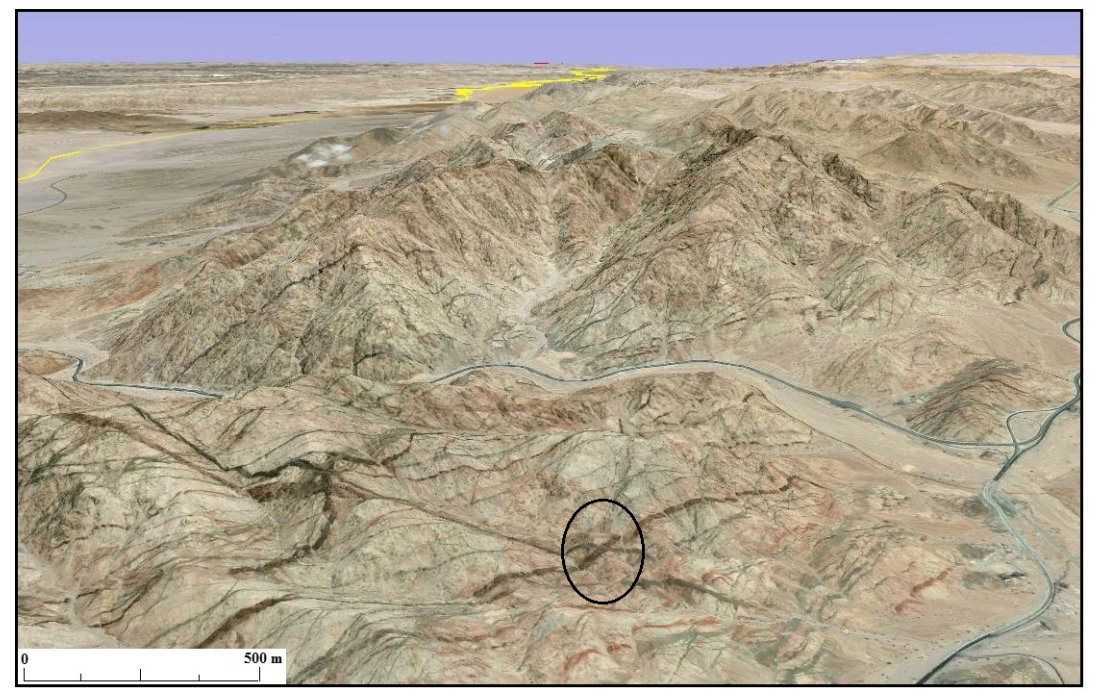

Figure 6. 3D-view for site 1 of the study area. Marked circle is the place where NW-SE striking dykes cut the NE-SW striking one

The analysis of the satellite image for the study area gives an excellent view of the dyke swarms that can not be viewed in field investigation. Al-Mokredi et al. (2007) and Raharimahefa and Kusky (2009) demonstrated how remote sensing data could be useful for mapping and extraction of the structural features. Visual interpretation of the images provided information about the distribution, type and orientations of the dykes in the study area. Use 
of remotely sensed imagery that provides a synoptic view for the dyke swarms enables mapping of these dykes of the study area.

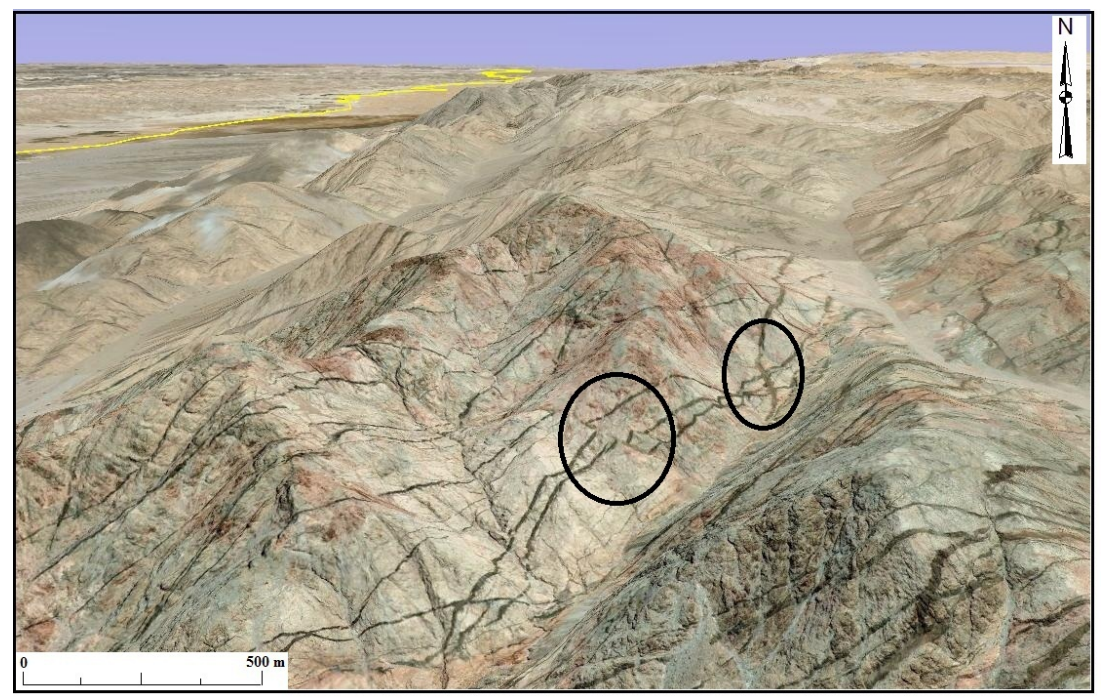

Figure 7. 3D-view for site 3 of the study area. Marked small circle is the place where N-S striking dykes cut the NE-SW striking one. While the bigger circle is the place where the dykes are truncated by fault

\section{Results and Discussion}

Visual interpretation of Landsat TM5 bands 7, 3 and 2 based on context, structure and texture of the image objects allowed mapping most of the dyke swarm in the study area. Bands 7, 3 and 2 were more clearly visible for the dyke swarms than other bands. Using linear stretching procedure gave the dykes different tones than the hosted rocks. The results of application of the digital analysis to the Landsat image of the study area provide information on mapping of the dyke swarms in the study area. Using bands 7, 3 and 2 for displaying the image and then subjected to linear contrast stretching process provides a good result for such mapping of the dykes in such area. Linear contrast stretching gives an image of differences between the intruded dykes and the hosted rocks.

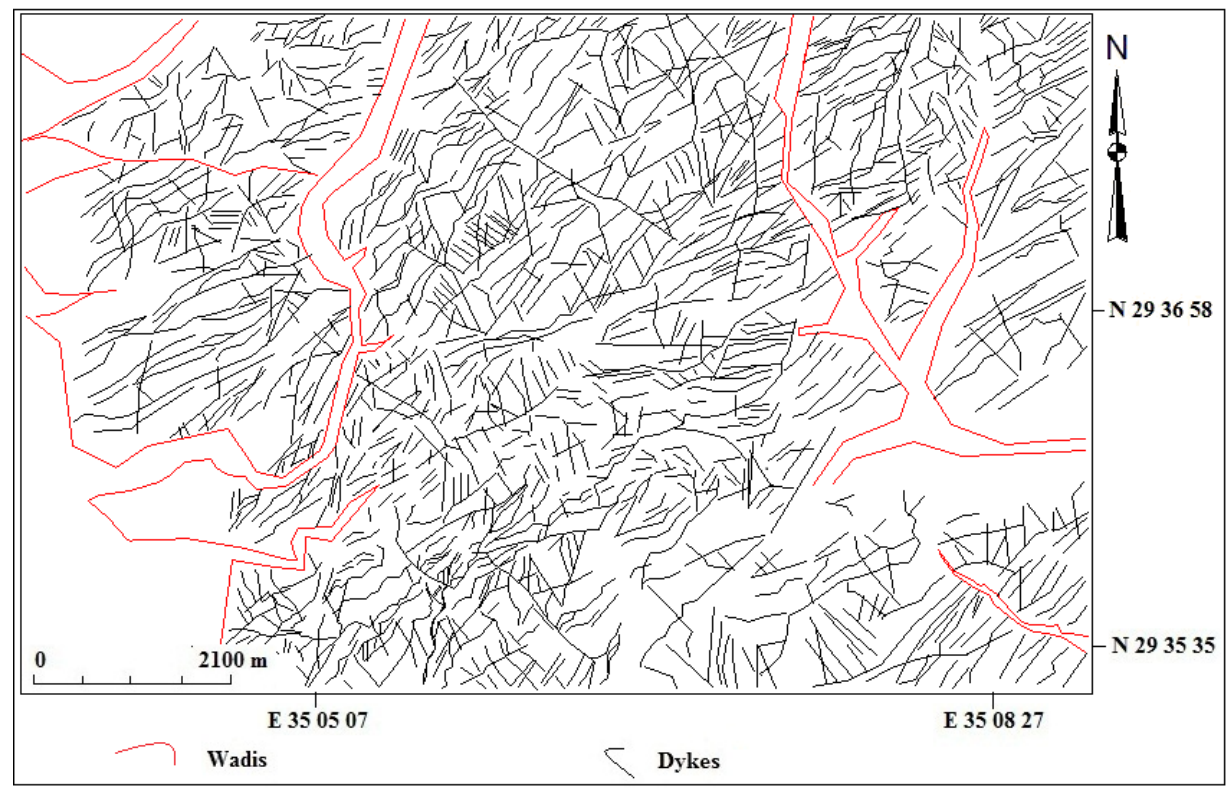

Figure 8. Delineated dykes in site 1 of the study area 


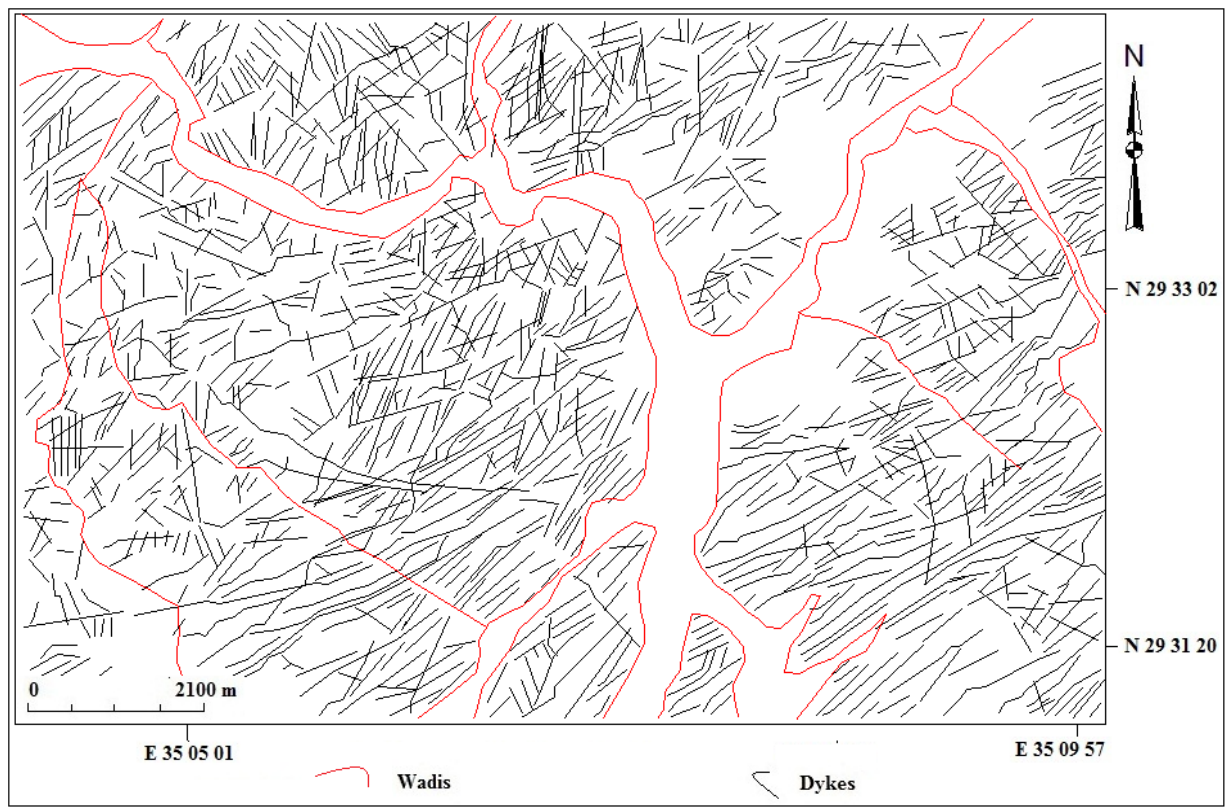

Figure 9. Delineated dykes in site 2 of the study area

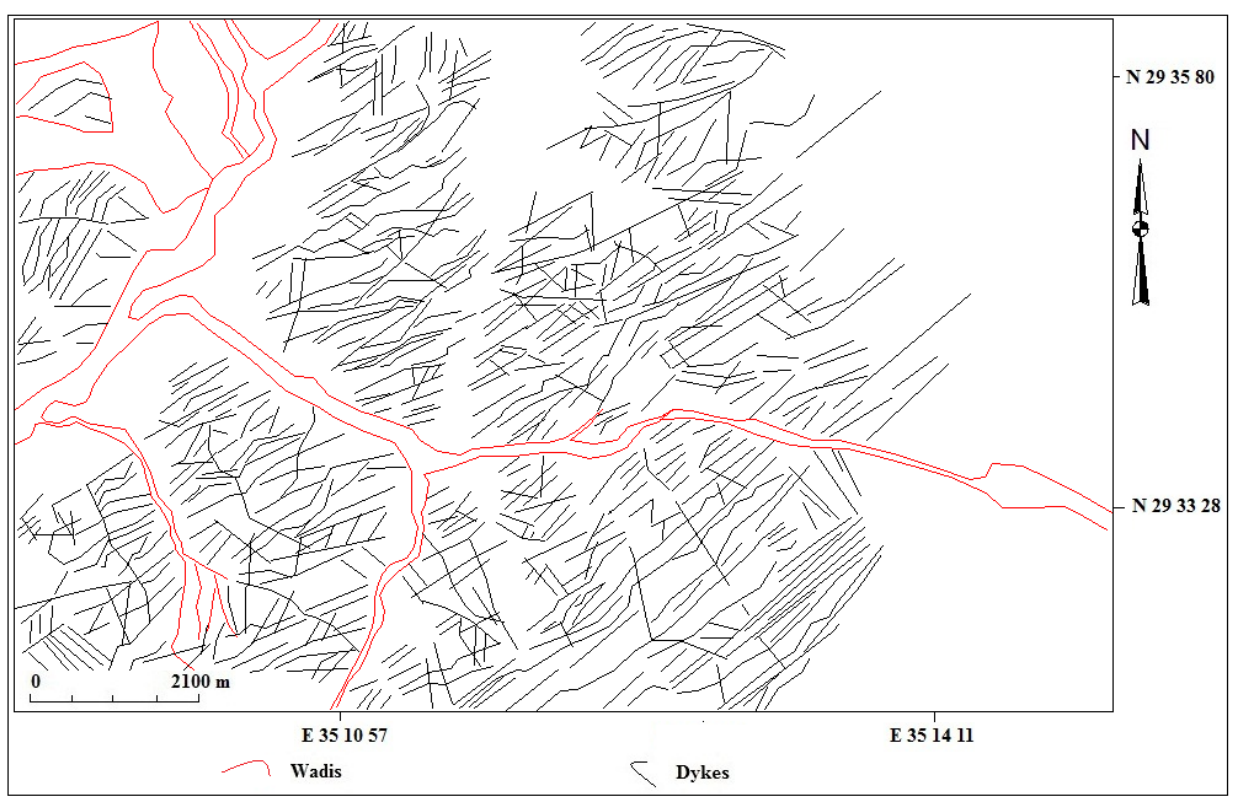

Figure 10. Delineated dykes in site 3 of the study area

The interpretation shows, for the first time, that there are four suites of dykes intruded the Neoproterozoic rocks in southwest Jordan. They are striking E-W, NE-SW, N-S and NW-SE directions with the NE-SW striking dykes are the abundant ones. This can be inferred from the cross-cutting relationship of the dykes as observed at the images. Interpretation of satellite image shows that the NE-SW dykes cut the E-W ones (Figure 5) and hence they are younger. The N-S striking dykes cut the NE-SW ones (Figure 7), so they are younger. The NW-SE striking dykes cut the NE-SW ones (Figure 6). Since the N-S striking dykes is younger than the NE-SW striking dykes, hence the NW-SE striking dykes is younger that the N-S striking ones. Therefore, the suites of dykes can be arranged from oldest to youngest as: E-W, NE-SW, N-S and NW-SE respectively.

Zaineldeen et al. (2002) introduced two sets of dykes intrusion in southwest of Jordan striking NE-SW and N-S with NE-SW striking dykes being the oldest. They gave a minimum age of $570 \mathrm{Ma}$ for the NE-SW striking dykes and caused by NE-SW $S_{\mathrm{Hmax}}$ strike-slip extensive regime (transtensive). While the N-S striking dykes have a maximum age of $560 \mathrm{Ma}$ and caused by N-S S $\mathrm{S}_{\mathrm{Hmax}}$ strike-slip extensive regime (transtensive). 


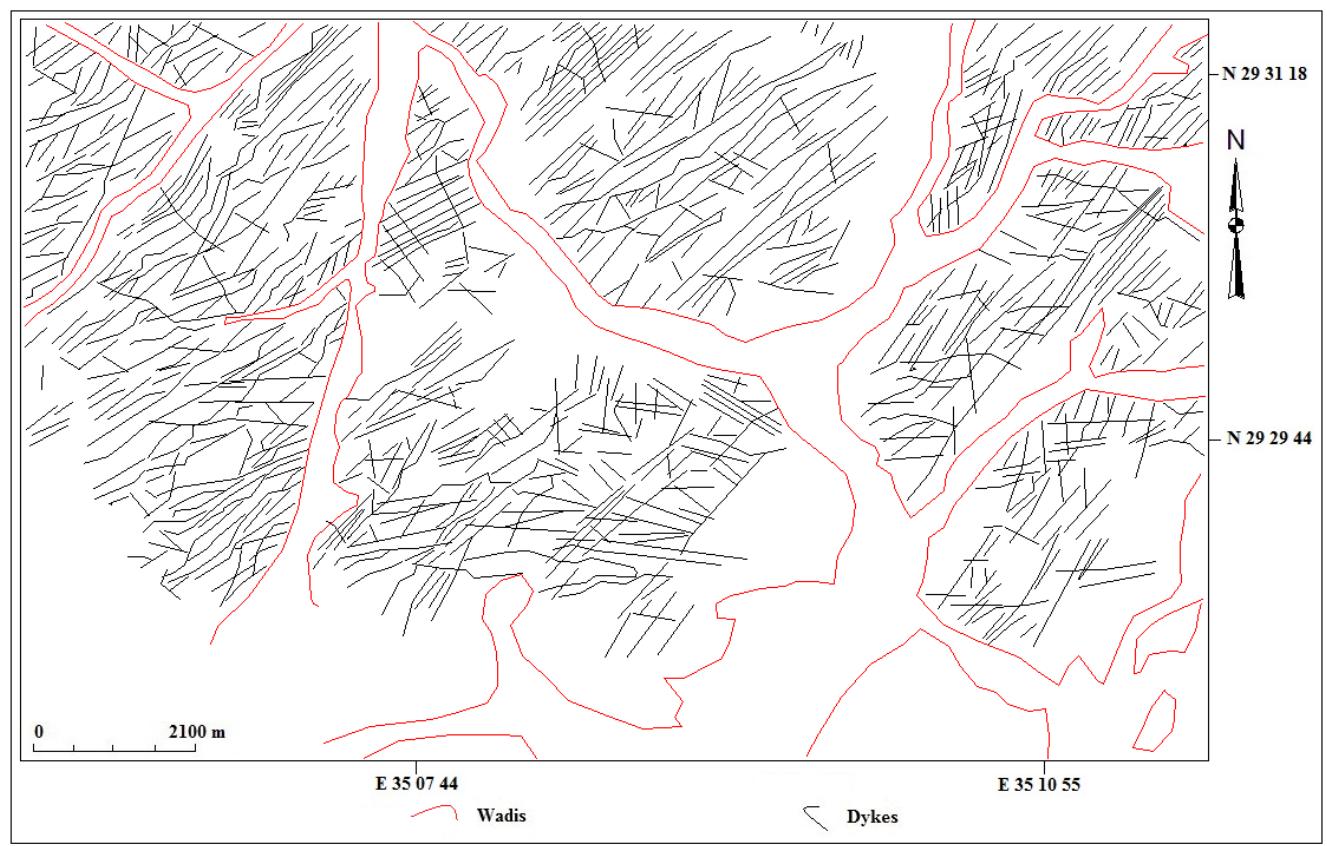

Figure 11. Delineated dykes in site 4 of the study area

The presence of these dykes indicates that the area was affected by great tensional stresses, and the cracks which created by these stresses where subsequently filled by molten rock. The existence of the four suites of dykes suggested a common source, with the different suites related by differences in melting or crystallization regimes. The evidence of tectonomagmatic environment in the study area during the intrusion of these dykes indicates strong extensional stress regime. Some dykes are truncated by faults (Figure 7).

It can be inferred that the last stage of Pan-African evolution of the Arabian-Nubian Shield ( $600-540 \mathrm{Ma})$ was marked by extension and emplacement of several generations of dykes. Four of these dykes are clearly identifiable in Jordan as presented in the current work (E-W, NE-SW, N-S and NW-SE striking dykes). The presence of these dykes within the basement indicates that the area is characterized by zone of weakness and affected strongly by tectonic movement.

It can be also inferred from the direction of suites of dykes that there is an anticlockwise rotation of the extensional stress regimes that caused these dykes during the Precambrian time (Neoproterozoic) and before the deposition of the Cambrian sediments.

\section{Conclusion}

Four suites of dykes are documented for the first time in the basement rocks in southwest Jordan at the end of the Neoproterozoic. Landsat image of the study area was analyzed by digital image processing technique using ENVI 4.7 software in order to map the dyke swarms in southwest Jordan. The enhancement technique performed include linear contrast stretching which introduced the most useful in distinguishing the intruded dykes and the hosted rocks. The introduced image enables to map the dyke swarms in the study area.

The results shows that the oldest suites of dyke strike E-W followed by suites strike NE-SW, N-S and NW-SE. The existence of these dykes indicates a strong extensional tectonic stresses affected the Neoproterozoic rocks in southwest Jordan. Remote sensing and GIS technique were used in the study to map the dykes suites in the study area. The method allowed mapping of these dykes. Landsat Thematic Mapper imagery provides an effective tool for such mapping on the basis of visual contextual interpretation of color composites. Remote sensing and GIS technique used here could thus guide the interpretation and provide exact and accurate dyke mapping tools.

\section{References}

Al-Mokredi, M. S., Guangdao, H., \& Ai-Bassam, B. (2007). Using remote sensing data to delineate the lineaments for hydrothermal mineral prediction in the Heging area northwest Yunnan Province, China. $\begin{array}{llll}\text { Journal of China University of Geosciences, } & 18(2), & 142-147 .\end{array}$ http://dx.doi.org/10.1016/S1002-0705(07)60028-4 
Bentor, Y. K. (1985). The crustal evolution of the Arabian-Nubian massif with special reference to the Sinai Peninsula. Precambrian Research, 28, 1-74. http://dx.doi.org/10.1016/0301-9268(85)90074-9

Beyth, M., Stern, R. J., Altherr, R., \& Kroner, A. (1994). The late Precambrian Timna igneous complex, southern Israel. Evidence for comagmatic monzodiorite 'sanukitoid' and alkali granite magma. Lithos, 31, 103-124. http://dx.doi.org/10.1016/0024-4937(94)90003-5

Beyth, M., Stern, R. J., Altherr, R., Peltz, S., \& Heimann, A. (1995). Petrochemistry of dolerite dikes from mount Timna, southern Israel: Implications for plate tectonic setting. Geological Survey of Israel Current Research, 9, 24-26.

Friz-Töpfer, A. (1991). Geochemical characterisation of Pan-African dyke swarms in southern Sinai: From continental margin to intraplate magmatism. Precambrian Research, 49, 281-300. http://dx.doi.org/10.1016/0301-9268(91)90038-C

Ibrahim, K., \& McCourt, W. J. (1995). Neoproterozoic granitic magmatism and tectonic evolution of the northern Arabian Shield: evidence from Southwest Jordan. Journal of African Earth Sciences, 20(2), 103-118. http://dx.doi.org/10.1016/0899-5362(95)00037-T

Jackson, N. J., Walsh, J. N., \& Pegram, E. (1984). Geology, geochemistry and petrogenesis of late Precambrian granitoids in the Central Hijaz Region of the Arabian Shield. Contrib. Mineral. Petrol., 87, 205-219. http://dx.doi.org/10.1007/BF00373054

Jarrar, G. (1985). Late Proterozoic crustal evolution of the Arabian-Nubian shield in the Wadi Araba area, SWJordan. Geologisches Jahrbuch B, 61, 3-87.

Jarrar, G., Wachendoref, H., \& Saffarini, G. (1992). A late Proterozoic bimodal volcanic/sub volcanic suite from Wadi Araba, Southwest Jordan. Precambrian Research, 56, 51-72. http://dx.doi.org/10.1016/0301-9268(92)90083-Z

Jarrar, G., Wachendoref, H., \& Zellmer, H. (1991). The Saramuj conglomerate: Evolution of a pan-African molasse sequence from southwest Jordan. Neues Jahrbuch für Geologie und Paläontologie, Monatsheft, 3, 335-356.

Kessel, R., Stein, M., \& Navon, O. (1998). Petrogenesis of late Neoproterozoic dikes in the northern Arabian-Nubian shield: Implications for the origin of A-type granites. Precambrian Research, 92, 195-213. http://dx.doi.org/10.1016/S0301-9268(98)00075-8

Lillesand, T. M., \& Kiefer, R. W. (1979). Remote sensing and image interpretation. New York: John Wily \& Sons. Chichester. Bisbane. Toronto, Singapore.

Pudlo, D., \& Franz, G. (1994). Dike rock generation and magma interactions in the Bir Safsaf igneous complex, SW Egypt: Implications for the Pan-African evolution in North East Africa. Geologische Rundschau, 83, 523-536. http://dx.doi.org/10.1007/BF01083225

Raharimahefa, T., \& Kusky, T. (2009). Structural and remote sensing analysis of the Betsimisaraka Suture in northeastern Madagascar. Gondwana Research, 15(1), 14-27. http://dx.doi.org/10.1016/j.gr.2008.07.004

Stern, R. J. (1985). The Najd-fault system, Saudi Arabia and Egypt: A late Precambrian rift-related transform system? Tectonics, 4, 497-511. http://dx.doi.org/10.1029/TC004i005p00497

Stern, R. J. (1994). Arc assembly and continental collision in the Neoproterozoic east African Orogen: implications for the consolidation of the Gondwanaland. Annual Review Earth Planetary Sciences, 22, 319-51. http://dx.doi.org/10.1146/annurev.ea.22.050194.001535

Stern, R. J., \& Gottfried, D. (1986). Petrogenesis of a late Precambrian (575-600 Ma) bimodal suite in Northeast Africa. Contrib. Mineral. Petrol., 92, 492-501. http://dx.doi.org/10.1007/BF00374431

Stern, R. J., \& Manton, W. I. (1987). Age of Feiran basement rocks, Sinai: implications for Late Precambrian crustal evolution in the northern Arabian-Nubian Shield. Journal Geological Society London, 144, 569-575. http://dx.doi.org/10.1144/gsjgs.144.4.0569

Stern, R. J., \& Voegeli, D. A. (1987). Geochemistry, geochronology and petrogenesis of a late Precambrian (590 Ma) composite dike from north eastern desert of Egypt. Geol. Rundsch., 76, 325-341. http://dx.doi.org/10.1007/BF01821078 
Stern, R. J., Sellers, G., \& Gottfried, D. (1988). Bimodal dike swarms in the Northeastern Desert of Egypt: significance for the origin of late Precambrian 'A-type' granites in northern Afro-Arabia. In: E. Gaby, Greiling (Eds.), The Pan-African Belt of Northeast Africa and Adjacent Areas (pp. 147-182).

Stoeser, D. B., \& Camp, V. E. (1985). Pan-African microplate accretion of the Arabian Shield. Geological $\begin{array}{lllll}\text { Society } & \text { of } & \text { Bmerica } & \text { 8ulletin, }\end{array}$ http://dx.doi.org/10.1130/0016-7606(1985)96<817:PMAOTA >2.0.CO;2

Zaineldeen, U., Delvaux, D., \& Jacobs, P. (2002). Tectonic evolution in the Wadi Araba segment of the Dead Sea Rift, South-West Jordan, vol. 2. European Geophysical Society (Special Publication Series, 63-81). 